\title{
ANALISIS KEMAMPUAN PEMAHAMAN KONSEP MATEMATIS MAHASISWA PADA MATA KULIAH KALKULUS II
}

\author{
Ayu Yarmayani ${ }^{1}$, Risma Simamora ${ }^{2}$ \\ Dosen Program Studi Pendidikan Matematika, FKIP, Universitas Batanghari Jambi ${ }^{1,2}$ \\ E-mail: ayu.yarmayani@unbari.ac.id
}

\begin{abstract}
ABSTRAK
Kalkulus merupakan salah satu matakuliah wajib bagi mahasiswa program studi pendidikan matematika yang bertujuan untuk membekali mahasiswa pada pemahaman konsep-konsep kalkulus. Aktivitas penyelesaian masalah akan telaksana jika mahasiswa memahami konsepkonsep matematika yang terkait langsung dengan masalah yang akan diselesaikan. Penelitian ini bertujuan untuk memperoleh deskripsi mengenai kemampuan pemahaman konsep matematis mahasiswa program studi pendidikan matematika. Subjek pada penelitian ini dipilih berdasarkan teknik purposive sampling dengan 5 (lima) orang subjek penelitian. Hasil penelitian menunjukkan bahwa kemampuan pemahaman konsep matematis pada indikator menyatakan ulang sebuah konsep sekitar 60\% yang dapat memenuhi dan 40\% tidak dapat memenuhi, pada indikator menyajikan konsep dalam berbagai bentuk representasi matematis sekitar $60 \%$ yang dapat memenuhi dan $40 \%$ tidak dapat memenuhi, pada indikator mengembangkan syarat perlu atau syarat cukup dari suatu konsep sekitar $80 \%$ yang dapat memenuhi dan $20 \%$ tidak dapat memenuhi dan pada indikator menggunakan, memanfaatkan dan memilih prosedur tertentu sekitar $40 \%$ yang dapat memenuhi dan $60 \%$ tidak dapat memenuhi indikator tersebut.
\end{abstract}

\section{Kata Kunci:}

Kalkulus; Kemampuan Pemahaman Konsep Matematis

\begin{abstract}
Calculus is one of the compulsory subjects for students of mathematics education study program which aims to equip students to understand calculus concepts. Problem solving activities will be successful if students understand mathematical concepts that are directly related to the problem to be solved. This study aims to obtain a description of the ability to understand mathematical concepts in mathematics education students. Subjects in this study were selected based on purposive sampling technique with 5 (five) research subjects. The results showed that the ability to understand mathematical concepts on indicators restated a concept of about $60 \%$ which could fulfill and $40 \%$ could not fulfill, on indicators presenting concepts in various forms of mathematical representation about $60 \%$ which could fulfill and $40 \%$ could not fulfill, at indicators develop necessary or sufficient conditions of a concept of about $80 \%$ that can fulfill and $20 \%$ cannot fulfill and on indicators of using, utilizing and selecting certain procedures, about $40 \%$ can fulfill and $60 \%$ cannot fulfill these indicators.
\end{abstract}

Keywords:

Calculus; The Ability to Understand Mathematical Concepts

\section{PENDAHULUAN}

Fakultas Keguruan dan Ilmu Pendidikan merupakan lembaga yang akan menciptakan calon guru kelak akan mendidik peserta didiknya. Karakteristika mahasiswa secara umum yaitu stabilitas dalam kepribadian yang mulai meningkat. Mahasiswa cenderung memantapkan dan berpikir dengan matang terhadap sesuatu yang akan diraihnya, sehingga mereka memiliki pandangan yang realistik tentang diri sendiri dan lingkungannya. Mahasiswa akan memperdalam keahlian dibidangnya masing-masing untuk mempersiapkan diri menghadapi dunia kerja.

Kalkulus merupakan salah satu matakuliah wajib bagi mahasiswa program studi pendidikan matematika yang bertujuan untuk membekali mahasiswa pada pemahaman konsep-konsep kalkulus.Salah satu konsep kalkulus yang harus dipahami mahasiswa adalah integral 


\section{$\pi$ (Phi)}

fungsi. Sejalan dengan pendapat Martono (Usman dkk, 2015) bahwa kalkulus salah satu matakuliah yang perlu dikuasai dengan baik oleh mahasiswa sains dan rekayasa sebagai suatu alat dalam proses pemecahan dan menyelesaikan berbagai masalah dalam ilmu pengetahuan dan teknologi.

Aktivitas-aktivitas menyelesaikan masalah akan terlaksana jika mahasiswa sudah memahami konsep-konsep matematika yang terkait langsung dengan masalah yang akan diselesaikan. Latar belakang pendidikan mahasiswa program studi pendidikan matematika tidak secara keseluruhan berasal dari sekolah menengah atas jurusan IPA. Hal ini merupakan catatan penting bagi seorang dosen untuk mengetahui konsep-konsep yang dimiliki mahasiswa agar pembelajaran berjalan dengan baik.

Dalam pembelajaran matematika, belajar konsep secara sederhana dapat dilakukan dengan mendengarkan, melihat, menangani dan berdiskusi. Susilana (2009) mengemukakan bahwa pembelajaran merupakan suatu kegiatan yang melibatkan seseorang dalam upaya memperoleh pengetahuan, keterampilan dan nilai-nilai positif dengan memanfaatkan berbagai sumber untuk belajar. Dalam menyampaikan konsep yang satu dengan konsep yang lain harus tidak saling bertentangan atau disampaikan secara sistematis. Peguasaan konsep merupakan tingkatan hasil belajar peserta didik sehingga dapat mendefenisikan atau menjelaskan sebagian bahan pelajaran dengan menggunakan kalimat sendiri.

Pemahaman konsep matematis adalah mengerti ide abstrak tentang suatu objek atau kejadian yang dibentuk dengan memandang sifat-sifat yang sama dari sekumpulan objek dalam hal menyatakan ulang sebuah konsep. Pemahaman konsep yang baik terjadi jika siswa mampu menguasai sejumlah materi pelajaran dan mampu mengungkapkan kembali dalam bentuk lain yang mudah dimengerti, memberikan interprestasi data dan mampu mengaplikasikan konsep yang sesuai dengan struktur kognitifnya. Pemahaman konsep juga memerlukan suatu keterampilan. Interaksi yang mengarah pada pencapaian keterampilan akan menuruti kaidah-kaidah tertentu dan bukan semata-mata hanya menghafal atau meniru.

Menurut Sagala (2013) Konsep merupakan pikiran seseorang atau sekelompok orang yang dinyatakan dalam definisi sehingga melahirkan produk pengetahuan meliputi prinsip, hukum, dan teori. Konsep diperoleh dari fakta, peristiwa, pengalaman, melalui generalisasi dan berpikir abstrak, kegunaan konsep untuk menjelaskan dan meramalkan. Kemampuan pemahaman konsep matematis adalah suatu proses mental terjadinya adaptasi dan transformasi ilmu pengetahuan dengan sistematis atau sesuai dengan langkahlangkah matematika. Dengan mentrasformasikan ilmu pengetahuan dengan sistematis materi akan lebih mudah untuk dipahami masuk kedalam otak oleh peserta didik, sehingga hasil pembelajaran bisa dipahami dalam jangka waktu yang lama.

Pemahaman konsep merupakan kompetensi yang ditujukan peserta didik dalam memahami konsep dan dalam melakukan prosedur (algoritma) secara luwes, akurat, efisien dan tepat. Indikator yang menunjukkan pemahaman konsep adalah sebagai berikut Hendriana (2017:

a) Kemampuan menyatakan ulang sebuah konsep.

b) Kemampuan mengklarifikasikan objek menurut sifat-sifat tertentu sesuai dengan konsepnya.

c) Kemampuan memberi contoh dan bukan contoh.

d) Kemampuan menyajikan konsep dalam berbagai bentuk representasi matematis.

e) Kemampuan mengembangkan syarat perlu atau syarat cukup dari suatu konsep. 


\section{$\pi$ (Phi)}

f) Kemampuanmenggunakan, memanfaatkan dan memilih prosedur tertentu.

g) Kemampuan mengaplikasikan konsep atau algoritma ke pemecahan masalah.

Indikator kemampuan pemahaman konsep matematis pada penelitian ini meliputi: (a) Kemampuan menyatakan ulang sebuah konsep; (b) Kemampuan menyajikan konsep dalam berbagai bentuk representasi matematis; (c) Kemampuan mengembangkan syarat perlu atau syarat cukup dari suatu konsep; (d) Kemampuan menggunakan, memanfaatkan dan memilih prosedur tertentu.

Penilaian pemahaman konsep bertujuan untuk mengetahui sejauh mana peserta didik mampu menerima dan memahami konsep dasar matematika yang telah diterima. Alat ukur yang digunakan untuk mengukur kemampuan pemahaman konsep matematis peserta didik adalah soal tes uraian. Soal bentuk uraian yang diberikan pada penelitian ini berdasarkan indikator kemampuan pemahaman konsep matematis pada setiap butir soal. Kriteria penilaian untuk setiap butir soal tes kemampuan pemahaman konsep matematis menggunakan rubrik analitik.Rubrik analitik adalah pedoman untuk menilai berdasarkan beberapa kriteria yang ditentukan.Guna mengevaluasi kemampuan pemahaman konsep matematis peserta didik, dilakukan pensekoran terhadap jawaban untuk setiap butir soal.

Proses penguasaan konsep yang baik adalah proses pemaknaan konsep, mahasiswa tidak hanya sekedar mengingat dan menghafal konsep melainkan memahami dan memaknai konsep tersebut. Sedangkan saat ini penguasaan siswa terhadap konsep matematika masih dirasa sulit bahkan dipahami dengan keliru. Sebagaimana dikemukakan Ruseffendi (Rohana, 2009) bahwa terdapat banyak peserta didik yang setelah belajar matematika, tidak mampu memahami bahkan pada bagian yang paling sederhana sekalipun, banyak konsep yang dipahami secara keliru sehingga matematika dianggap sebagai ilmu yang sukar, ruwet dan banyak memberdayakan.

Berdasarkan uraian di atas maka penelitian yang akan dilakukan dengan judul Analisis Kemampuan Pemahaman Konsep Matematis Mahasiswa pada Mata Kuliah Kalkulus II.

\section{METODE PENELITIAN}

Penelitian ini ditinjau dari jenisnya termasuk penelitian kualitatif.Metode penelitian kualitatif merupakan metode penelitian yang digunakan untuk meneliti pada kondisi objek yang alami. Adapun pendekatan dalam penelitian ini adalah pendekatan deskriptif yang bertujuan untuk mendeskripsikan apa yang saat ini berlaku. Menurut Bogdan dan Taylor (Rofiqoh, 2015) pendekatan kualitatif adalah suatu prosedur penelitian yang menghasilkan data berupa kata-kata tertulis atau lisan dari orang-orang dan perilaku yang dapat diamati.

Penelitian ini terdapat upaya untuk mendeskripsikan, mencatat, analisis dan menginterpretasikan kondisi-kondisi yang terjadi.Permasalahan yang dideskripsikan dalam penelitian ini adalah kemampuan pemahaman konsep matematis mahasiswa.Untuk mendeskripsikan kemampuan tersebut dilakukan penelusuran dengan pengamatan langsung yaitu dengan menganalisis hasil tes kemampuan pemahaman konsep matematis yang dikerjakan dan kemudian dilakukan wawancara semi terstruktur.

Sumber data dalam penelitian ini adalah mahasiswa pada mata kuliah Kalkulus II. Dari sumber data tersebut dipilih subjek berdasarkan tes kemampuan pemahaman konsep matematis.Teknik pemilihan subjek penelitian yang digunakan adalah teknik Purposive Sampling.Menurut Sugiyono (2008) purposive sampling adalah teknik pengambilan subjek sumber data dengan pertimbangan dan tujuan tertentu. 


\section{$\pi$ (Phi)}

Tes kemampuan pemahaman konsep matematis yang digunakan peneliti adalah soal uraian.Lembar soal dalam penelitian ini adalah lembar soal yang berisikan materi integral. Soal dibuat berdasarkan silabus pada mata kuliah kalkulus II dan kemudian disusun dengan kisi-kisi berdasarkan tingkatan soal selanjutnya setiap soal yang digunakan telah melaui proses validasi isi. Validasi soal dikaitkan dengan RPS, bahasa yang dipakai dan kesesuaian dengan subjek penelitian.

Wawancara menurut Moleong (2012) adalah suatu percakapan yang dilakukan oleh dua pihak yaitu pewawancara yang mana mengajukan pertanyaan dan terwawancara yang memberikan jawaban atas pertanyaan yang diajukan oleh pewawancara.Sedangkan menurut Sugiyono (2007) wawancara adalah pertemuan dua orang untuk bertukar informasi dan ide melalui Tanya jawab, sehingga dikonstruksikan makna dalam suatu topic tertentu.

Pedoman wawancara ini digunakan untuk menggali informasi lebih mendalam mengenai jawaban tes kemampuan pemahaman konsep matematis dalam menyelesaikan soal integral.Pedoman wawancara ini menggunakan wawancara semiterstruktur dengan merumuskan pertanyaan-pertanyaan terlebih dahulu. Jenis wawancara ini sudah termasuk dalam kategori in depth interview dimana dalam pelaksanaannya lebih bebas bila dibandingkan dengan wawancara terstruktur.

Hasil data wawancara berupa transkrip wawancara yang berisi pertanyaan peneliti dan jawaban mahasiswa dalam menyelesaikan tes kemampuan pemahaman konsep matematis.Berdasarkan transkrip tersebut, data tentang siswa dalam menyelesaikan tes kemampuan pemahaman konsep dapat dideskripsikan.

Analisa data merupakan proses sistematis pencarian dan pengaturan transkipsi wawancara, catatan lapangan, dan materi-materi lain yang telah dikumpulkan untuk meningkatkan pemahaman mengenai materi-materi dan untuk menyajikan apa yang sudah kita temukan dari orang lain.Data dalam penelitian ini berupa data dari hasil tes kemampuan pemahaman konsep matematis. Data yang diperoleh dari hasil tes akan dianalisis, tujuannya untuk menyederhanakan data ke dalam bentuk yang dapat dimengerti dengan jelas. Teknis analisis data yang digunakan dalam penelitian ini adalah analisis data kualitatif.Menurut Milles dan Huberman (Sugiyono, 2007) mengemukakan bahwa aktifitas dalam analisis data kualitatif dilakukan secara interatif dan berlangsung secara terus menerus sampai tuntas, sehingga datanya sudah jenuh.

Analisis data wawancara (kualitatif) dalam penelitian ini dianalisis dengan menggunakan teknik analisis yang mengacu pada pendapat Miles dan Huberman (1992) yang meliputi : (1) reduksi data, (2) pemaparan data/kategorisasi, dan (3) penarikan kesimpulan. Reduksi data adalah proses pemilihan, pemusatan perhatian pada penyederhanaan data kasar di lapangan. Reduksi data yang dilakukan dalam penelitian ini yaitu kegiatan yang mengacu pada proses pemilihan dan pengidentifikasian data yang memiliki makna jika dikaitkan dengan pertanyaan penelitian dan selanjutnya membuat kode pada setiap satuan sehingga diketahui berasal dari sumber mana.

Pemaparan data/kategorisasi meliputi pengklasifikasian dan identifikasi data, yaitu menuliskan kumpulan data yang terorganisai dan terkategori sehingga memungkinkan untuk menarik kesimpulan berdasarkan data tersebut.Penarikan kesimpulan didasarkan pada hasil analisis terhadap data yang telah terkumpul baik hasil pekerjaan tertulis maupun yang diperoleh dari hasil wawancara. 
$\pi$ (Phi)

HASIL DAN PEMBAHASAN

Instrument tes kemampuan pemahaman konsep yang berguna untuk mengetahui kemampuan pemahaman konsep ini divalidasi oleh 2 (dua) orang ahli matematika. Validasi isi terhadap lembar tes kemampuan pemahaman konsep matematis meliputi: (1) Penilaian terhadap konstruksi soal; (2) Penilaian terhadap bahasa soal; (3) Penilaian terhadap materi soal.

Hasil validasi isi yang telah dinilai oleh 2 (dua) orang ahli matematika menyatakan bahwa sangat setuju sebesar $29 \%$, setuju $57 \%$ dan ragu-ragu $14 \%$ terhadap penilaian konstruksi soal, penilaian terhadap bahasa soal serta penilaian terhadap materi soal. Berdasarkan hasil tersebut dapat diketahui bahwa instrument tes dapat digunakan sebagai alat ukur terhadap kemampuan pemahaman konsep matematis.

Berdasarkan hasil tes dan hasil wawancara pada 5 (lima) orang subjek untuk mengukur kemampuan pemahaman konsep matematis dengan 4 (empat) indikator kemampuan dapat dijelaskan sebagai berikut.

\section{Kemampuan Pemahaman Konsep Mahasiswa pada Indikator Menyatakan Ulang Konsep}

Berdasarkan kutipan wawancara dan hasil jawaban diketahui bahwa subjek A dapat menjelaskan jawaban yang dituliskan dengan menjelaskan konsep apa yang digunakan untuk menyelesaikan soal tersebut. Hal ini dapat dilihat dari kutipan wawancara J2SA yaitu menjelaskan konsep integral terhadap diferensial yang diketahui untuk menentukan fungsi $\mathrm{F}(\mathrm{x})$. Namun, subjek A tidak dapat menuliskan langkah penyelesaian dengan sistematis dan tepat. Berdasarkan hal tersebut diketahui bahwa subjek A dapat memenuhi indikator kemampuan pemahaman konsep pertama yaitu menyatakan ulang sebuah konsep.
Berdasarkan kutipan wawancara dan hasil jawaban di atas, kemampuan pemahaman konsep subjek B yaitu subjek mengetahui langkah yang dikerjakan untuk mengoperasikan diferensial dengan konsep integral.Selain itu, subjek juga mampu menyajikan jawaban dengan baik dan sistematis. Hal ini dapat dilihat dari kutipan wawancara J2SB yaitu subjek mampu mengintegralkan fungsi F” untuk mendapatkan fungsi $F$ ' lalu mengantikan nilai $F^{\prime}(4)=10$ untuk mendapatkan nilai c kemudian mengintegralkan lagi fungsi $F$ ' agar mendapatkan $\mathrm{F}(\mathrm{x})$. Dari hal tersebut dapat dikatakan bahwa subjek B dapat memenuhi dengan lengkap indikator kemampuan pemahaman konsep matematis yang pertama yaitu menyatakan ulang sebuah konsep.

Berdasarkan kutipan wawancara dan hasil jawaban di atas, diketahui bahwa subjek $\mathrm{C}$ tidak dapat menggunakan konsep integral dan tidak menjelaskan dengan baik jawaban yang dituliskan.Hal ini disebabkan subjek $\mathrm{C}$ belum mampu mengubah bentuk akar menjadi bilangan berpangkat, sehingga subjek $\mathrm{C}$ tidak mampu menggunakan konsep integral untuk penyelesaian soal tersebut.Dari hal tersebut dapat dikatakan bahwa subjek C tidak dapat memenuhi indikator kemampuan pemahaman konsep matematis yang pertama yaitu menyatakan ulang sebuah konsep.

Berdasarkan kutipan wawancara dan hasil jawaban diketahui bahwa subjek D dapat menjelaskan jawaban yang dituliskan dengan menjelaskan konsep apa yang digunakan untuk menyelesaikan soal tersebut. Namun, subjek D hanya mampu menyajikan perhitungannya saja tidak dengan lengkap dan sistematis penyelesaian pada soal tersebut.Dari hal tersebut dapat dikatakan bahwa subjek D dapat memenuhi indikator kemampuan pemahaman konsep matematis yang pertama yaitu menyatakan ulang sebuah konsep. 


\section{$\pi$ (Phi)}

Subjek menunjukkan hal berbeda pada penyelesaian soal sangat sistematis atau hanya sebuah perhitungan saja. Berdasarkan hasil jawaban 5 (lima) orang subjek diketahui bahwa hanya 4 (empat) orang subjek yang berusaha menyelesaikan soal dan 1 (satu) orang tidak memberikan jawaban. Hasil analisis kemampuan pemahaman konsep matematis diketahui bahwa $60 \%$ yang dapat memenuhi indikator menyatakan ulang sebuah konsep dan $40 \%$ belum dapat memenuhi indikator menyatakan ulang sebuah konsep.

\section{Kemampuan Pemahaman Konsep Mahasiswa pada Indikator Menyajikan Konsep dalam Berbagai Bentuk Representasi Matematis}

Berdasarkan kutipan wawancara dan hasil jawaban diketahui bahwa subjek A dapat menjelaskan jawaban yang dituliskan dengan menjelaskan langkahlangkah apa yang digunakan untuk menyelesaikan soal tersebut. Dari hal tersebut dapat dikatakan bahwa subjek A dapat memenuhi indikator kemampuan pemahaman konsep matematis yang kedua yaitu menyajikan konsep dalam berbagai bentuk representasi matematis.

Berdasarkan kutipan wawancara dan hasil jawaban di atas, kemampuan pemahaman konsep subjek B yaitu subjek mengetahui prosedur penyelesaian untuk mengoperasikan diferensial dengan konsep integral agar mendapatkan persamaan.Selain itu, subjek juga mampu menyajikan jawaban dengan baik dan sistematis.Dari hal tersebut dapat dikatakan bahwa subjek B dapat memenuhi indikator kemampuan pemahaman konsep matematis yang kedua yaitu menyajikan konsep dalam berbagai bentuk representasi matematis.

Berdasarkan kutipan wawancara dan hasil jawaban di atas, diketahui bahwa subjek C tidak dapat menggunakan konsep integral dalam penyelesaian dan tidak menjelaskan dengan baik jawaban yang
dituliskannya.Dari hal tersebut dapat dikatakan bahwa subjek C tidak dapat memenuhi indikator kemampuan pemahaman konsep matematis yang kedua yaitu menyajikan konsep dalam berbagai bentuk representasi matematis.

Berdasarkan kutipan wawancara dan hasil jawaban diketahui bahwa subjek D dapat menjelaskan jawaban yang dituliskan dengan menjelaskan konsep apa yang digunakan. Namun, subjek D hanya mampu menyajikan sebagian perhitungan saja sehingga soal tersebut belum terselesaikan.Dari hal tersebut dapat dikatakan bahwa subjek D dapat memenuhi indikator kemampuan pemahaman konsep matematis yang kedua yaitu menyajikan konsep dalam berbagai bentuk representasi matematis.

Subjek menunjukkan hal berbeda pada penyelesaian soal sangat sistematis atau hanya sebuah perhitungan saja. Berdasarkan hasil jawaban 5 (lima) orang subjek diketahui bahwa hanya 4 (empat) orang subjek yang berusaha menyelesaikan soal dan 1 (satu) orang tidak memberikan jawaban. Hasil analisis kemampuan pemahaman konsep matematis diketahui bahwa 60\% yang dapat memenuhi indikator menyajikan konsep dalam berbagai bentuk representasi matematis dan $40 \%$ tidak dapat memenuhi indikator menyajikan konsep dalam berbagai bentuk representasi matematis.

\section{Kemampuan Pemahaman Konsep Mahasiswa pada Indikator Mengembangkan Syarat Perlu atau Syarat Cukup dari Suatu Konsep}

Berdasarkan kutipan wawancara dan hasil jawaban diketahui bahwa subjek A dapat menjelaskan secara lengkap jawaban yang dituliskan dengan menunjukkan unsur apa yang harus diketahui untuk menyelesaikan soal tersebut. Subjek A dapat mengembangkan syarat yang diperlukan untuk melakukan operasional pada integral parsial yaitu melakukan operasi diferensian pada u dan operasi 


\section{$\pi$ (Phi)}

integral pada dv. Hal ini dapat dilihat dari kutipan wawancara J2SB yaitu dengan mencari $\frac{\mathrm{du}}{\mathrm{dx}}$ dari fungsi $\mathrm{u}$ yang diketahui selanjutnya juga harus mencari $\mathrm{v}$ dari $\mathrm{dv}$ yang diketahui dengan cara integral. Dari hal tersebut dapat dikatakan bahwa subjek A dapat memenuhi indikator kemampuan pemahaman konsep matematis yang ketiga yaitu mengembangkan syarat perlu atau syarat cukup dari suatu konsep.

Berdasarkan kutipan wawancara dan hasil jawaban diketahui bahwa subjek B dapat menjelaskan jawaban yang dituliskan dengan menjelaskan operasi apa yang digunakan untuk menyelesaikan soal tersebut. Dari hal tersebut dapat dikatakan bahwa subjek B dapat memenuhi indikator kemampuan pemahaman konsep matematis yang ketiga yaitu mengembangkan syarat perlu atau syarat cukup dari suatu konsep.

Berdasarkan kutipan wawancara dan hasil jawaban di atas, diketahui bahwa subjek $C$ dapat menggunakan unsur yang diketahui untuk mendapatkan kecukupan unsur yang diperlukan pada rumus integral parsial. Namun,subjek C tidak dapat menuliskan dengan baik symbol pemisalan yang digunakan dan tidak dapa menjelaskan dengan baik jawaban yang dituliskannya. Dari hal tersebut dapat dikatakan bahwa subjek C dapat memenuhi indikator kemampuan pemahaman konsep matematis yang ketiga yaitu mengembangkan syarat perlu atau syarat cukup dari suatu konsep.

Dari kutipan wawancara dan hasil jawaban subjek D di atas, kemampuan pemahaman konsep subjek D yaitu subjek tidak memahami isi soal dan tidak memahami syarat unsure yang diperlukan pada soal.Dari hal tersebut dapat dikatakan bahwa subjek D tidak dapat memenuhi indikator kemampuan pemahaman konsep matematis yang ketiga yaitu mengembangkan syarat perlu atau syarat cukup dari suatu konsep.
Berdasarkan kutipan wawancara dan hasil jawaban diketahui bahwa subjek E dapat menjelaskan secara lengkap jawaban yang dituliskan dengan menunjukkan unsur apa yang harus diketahui untuk menyelesaikan soal tersebut. Dari hal tersebut dapat dikatakan bahwa subjek E dapat memenuhi indikator kemampuan pemahaman konsep matematis yang ketiga yaitu mengembangkan syarat perlu atau syarat cukup dari suatu konsep.

Subjek menunjukkan hal berbeda pada penyelesaian soal sangat sistematis atau hanya sebuah perhitungan saja. Hasil analisis kemampuan pemahaman konsep matematis diketahui bahwa $80 \%$ yang dapat memenuhi indikator mengembangkan syarat perlu atau syarat cukup dari suatu konsep dan 20\% tidak dapat memenuhi indikator mengembangkan syarat perlu atau syarat cukup dari suatu konsep.

\section{Kemampuan Pemahaman Konsep Mahasiswa pada Indikator Menggunakan, Memanfaatkan dan Memilih Prosedur Tertentu}

Berdasarkan kutipan wawancara dan hasil jawaban diketahui bahwa subjek A dapat menjelaskan jawaban yang dituliskan dengan menunjukkan unsur apa yang harus diketahui untuk menyelesaikan soal tersebut. Namun, subjek A tidak dapat menyelesaikan soal tersebut karena belum mengerti memanfaatkan prosedur integral pada integral parsial. Dari hal tersebut dapat dikatakan bahwa subjek A dapat memenuhi indikator kemampuan pemahaman konsep matematis yang keempat yaitu menggunakan, memanfaatkan dan memilih prosedur tertentu.

Berdasarkan kutipan wawancara dan hasil jawaban di atas, diketahui bahwa subjek B tidak dapat menggunakan konsep integral parsial dalam penyelesaian dan tidak menjelaskan dengan baik jawaban yang dituliskannya.Dari hal tersebut dapat dikatakan bahwa subjek B tidak dapat 


\section{$\pi$ (Phi)}

memenuhi indikator kemampuan pemahaman konsep matematis yang keempat yaitu menggunakan, memanfaatkan dan memilih prosedur tertentu.

Berdasarkan kutipan wawancara dan hasil jawaban di atas, diketahui bahwa subjek $\mathrm{C}$ tidak dapat menggunakan konsep integral parsial dalam penyelesaian dan tidak menjelaskan dengan baik jawaban yang dituliskannya.Dari hal tersebut dapat dikatakan bahwa subjek C tidak dapat memenuhi indikator kemampuan pemahaman konsep matematis yang keempat yaitu menggunakan, memanfaatkan dan memilih prosedur tertentu.

Dari kutipan wawancara dan hasil jawaban subjek D di atas, kemampuan pemahaman konsep subjek D yaitu subjek tidak memahami isi soal dan tidak memahami syarat unsur yang diperlukan pada soal.Dari hal tersebut dapat dikatakan bahwa subjek D tidak dapat memenuhi indikator kemampuan pemahaman konsep matematis yang keempat yaitu menggunakan, memanfaatkan dan memilih prosedur tertentu.

Berdasarkan kutipan wawancara dan hasil jawaban di atas, diketahui bahwa subjek E tidak dapat menggunakan konsep integral parsial dalam penyelesaian dan tidak menjelaskan dengan baik jawaban yang dituliskannya.Dari hal tersebut dapat dikatakan bahwa subjek E dapat memenuhi indikator kemampuan pemahaman konsep matematis yang keempat yaitu menggunakan, memanfaatkan dan memilih prosedur tertentu.

Subjek menunjukkan hal berbeda pada penyelesaian soal sangat sistematis atau hanya sebuah perhitungan saja. Hasil analisis kemampuan pemahaman konsep matematis diketahui bahwa $40 \%$ yang dapat memenuhi indikator menggunakan, memanfaatkan dan memilih prosedur tertentu dan $60 \%$ tidak dapat memenuhi indikator menggunakan, memanfaatkan dan memilih prosedur tertentu.

\section{SIMPULAN DAN SARAN}

Berdasarkan hasil penelitian terhadap kemampuan pemahaman konsep matematis mahasiswa dalam menyelesaikan soal integral pada mata kuliah Kalkulus II dapat disimpulkan bahwa:

1. Kemampuan pemahaman konsep matematis pada indikator menyatakan ulang sebuah konsep hanya sekitar $60 \%$ yang dapat memenuhi dan $40 \%$ belum dapat memenuhi indikator.

2. Kemampuan pemahaman konsep matematis pada indikator menyajikan konsep dalam berbagai bentuk representasi matematis hanya sekitar $60 \%$ yang dapat memenuhi dan $40 \%$ belum dapat memenuhi indikator.

3. Kemampuan pemahaman konsep matematis pada indikator mengembangkan syarat perlu atau syarat cukup dari suatu konsep hanya sekitar $80 \%$ yang dapat memenuhi dan $20 \%$ belum dapat memenuhi indikator.

4. Kemampuan pemahaman konsep matematis pada indikator menggunakan, memanfaatkan dan memilih prosedur tertentu hanya sekitar $40 \%$ yang dapat memenuhi dan $60 \%$ belum dapat memenuhi indikator.

Berdasarkan kesimpulan di atas, maka saran yang ingin peneliti sampaikan terkait hasil penelitian yang telah dilakukan yaitu deskripsi kemampuan pemahaman konsep matematis masih terbatas pada 2 (dua) soal yang mencakup hanya 4 (empat) indikator saja.Sehingga masih diperlukan penelitian lebih lanjut mengenai kemampuan pemahaman konsep matematis yang mencakup indikator lebih luas dan spesifik lagi. 


\section{DAFTAR PUSTAKA}

Hendriana, Heris. (2017). Hard Skills dan Soft Skills Matematik Siswa. Bandung: Refika Aditama.

Milles \& Huberman. (1992). Analisis Data Kualitatif (tentang metode-metode baru). Jakarta: UI-Press.

Moleong, L. J. (2012). Metodologi Penelitian Kualitatif. Bandung: PT. Remaja Rosdakarya.

Rofiqoh, Zeni. (2015). Analisis Kemampuan Pemecahan Masalah Matematika Siswa Kelas X dalam Pembelajaran Discovery Learning Berdasarkan Gaya Belajar Siswa. Skripsi. Semarang: Universitas Negeri Semarang.

Rohana. (2009). Penggunaan Peta Konsep dalam Pembelajaran Statistik Dasar di Program Studi Pendidikan Matematika FKIP. Jurnal Pendidikan Matematika, 3 (2), 92102.

Sagala, Syaiful. (2013). Konsep dan Makna Pembelajaran. Bandung: Alfabeta.

Sugiono. (2007). Memahami Penelitian Kualitatif. Bandung: Alfabeta

Sugiyono. (2008). Metode Penelitian Kuantitatif Kualitatif Dan $R \& D$. Bandung:Alfabeta.

Susilana, Rudi dan Riyana, Cepi. 2009. Media Pembelajaran Hakikat, Pengembangan, Pemanfaatan Dan Penilaian. Bandung: Wacana Prima.

Usman, dkk. (2015). Pemahaman Mahasiswa Calon Guru Matematika dalam Menyelesaikan Masalah Ketaksamaan Nilai Mutlak. Jurnal Peluang, 3(2), 13-23. 